\title{
Managing type 1 diabetes during the COVID-19 pandemic.
}

Ines CHARRADA ${ }^{1}$, Cyrine Bennasrallah ${ }^{1}$, Manel Ben Fredj ${ }^{1}$, Nadia Slimene ${ }^{1}$, Wafa Dhouib $^{1}$, Hela Abroug ${ }^{1}$, Imen Zemni ${ }^{1}$, Meriam Oumayma Beji ${ }^{1}$, Chawki Loussaief ${ }^{1}$, Ines Bouanène $^{1}$, and Asma Belguith Sriha ${ }^{1}$

${ }^{1}$ Faculté de medecine de Monastir

September 30, 2020

\begin{abstract}
We report 2 imported cases of COVID 19 in patients with type 1 diabetes. The viral shedding duration was 18 and 22 days in the two cases. Both patients had maintained correct blood glucose levels without ketoacidosis decompensation with regular medical follow-up by telephone.
\end{abstract}

\section{Hosted file}

article COVID19.pdf available at https://authorea.com/users/363163/articles/484028-managingtype-1-diabetes-during-the-covid-19-pandemic

\section{Hosted file}

table 1.pdf available at https://authorea.com/users/363163/articles/484028-managing-type-1diabetes-during-the-covid-19-pandemic

\section{Hosted file}

Table 2.pdf available at https://authorea.com/users/363163/articles/484028-managing-type-1diabetes-during-the-covid-19-pandemic 